\title{
$\mathrm{Li}_{4 / 3} \mathrm{Ti}_{5 / 3} \mathrm{O}_{4}$ を負極に用いたコイン型全固体リチウム二次電池の作動特性
}

\author{
岩本 和也 ${ }^{*}$, 高田 和典, 藤野 信, 近藤 繁雄
}

\section{Performance of Coin Type Solid State Battery with $\mathrm{Li}_{4 / 3} \mathrm{Ti}_{5 / 3} \mathrm{O}_{4}$ as Negative Electrode Material}

\author{
Kazuya IWAMOTO, ${ }^{*}$ Kazunori TAKADA, Makoto FUJINO, and Shigeo KondO \\ 松下電池工業侏技術研究所（示570-8511 守口市松下町 1 番 1 号) \\ Technology Laboratory, Matsushita Battery Industrial Co., Ltd. (1-1, Matsushita-cho, Moriguchishi, Osaka \\ 570-8511, Japan)
}

Received May 27, 1998 ; Accepted October 28, 1998

\begin{abstract}
Solid state lithium battery, $\mathrm{Li}_{4 / 3+x} \mathrm{Ti}_{5 / 3} \mathrm{O}_{4} / \mathrm{Li}_{1-x} \mathrm{CoO}_{2}$, was constructed by using a $\mathrm{Li}^{+}$ion conductive sulfide glass as an electrolyte. The coin type battery with dimensions of $12 \mathrm{~mm}$ in diameter and $1.6 \mathrm{~mm}$ in thickness had a discharge capacity of $2.8 \mathrm{mAh}$. The battery showed an excellent cycling ability. There was no degradation in coulombic efficiency even in the case of continuous charging. It suggests that side reaction is negligible due to the electrochemical stability of the solid electrolyte.
\end{abstract}

Key Words : Solid State Secondary Battery, Lithium Ion Conductive Glass, Lithium Titanium Oxide

\section{1 緒 言}

近年の移動体通信機器, 携帯情報端末機器, パーソナルコ ンピュータなどのポータブル機器の進歩と普及に伴い,これ ら機器の主電源に用いられる電池に対して高電圧・高エネル ギ一密度のリチウムイオン二次電池の用途が急速に拡大して いる。一方，半導体技術の進歩により，半導体メモリ一素子 の低電圧駆動化が進み，これにともない小型携帯電子機器に 使用されている半導体メモリーのバックアップ用電源も，4 $\mathrm{V}$ 級のいわゆるリチウム二次電池だけではなく，さらに低い 電圧で高エネルギー密度を有する電池の開発に対する要望も 增加してきている。

我々は，これまでに固体電解質 ${ }^{1-4)}$ として高いイオン電導 度 $\left(1.8 \times 10^{-3} \mathrm{~S} / \mathrm{cm}\right.$, 室温 $)$ を示す $\mathrm{Li}$ イオン伝導性オキシサル ファイドガラス $\left(\mathrm{Li}_{3} \mathrm{PO}_{4}-\mathrm{Li}_{2} \mathrm{~S}-\mathrm{SiS}_{2}\right)$ を用い，正極活物質と してコバルト酸りチウム $\left(\mathrm{LiCoO}_{2}\right)$ ，負極活物質として金属 インジウム(In)箔を用いた，3.5 V 級の粉末成型法による $\mathrm{R} 2016$ サイズ (直径 $20 \mathrm{~mm}$, 厚さ $1.6 \mathrm{~mm}$ )のコイン型の全 固体りチウム二次電池を作製，その特性を報告してきた5)。

一般に, 有機電解液系リチウム電池の負極活物質として, 金属インジウムを使用すると，電池の充放電にともなって， リチウムイオンの㨂入・脱離時に大きな体棈变化が生じる結 果, 金属インジウムの集電体からの脱落が起こり，充放電サ イクルにともなう特性の劣化が著しい材料であることが報告 されている67.これに対して，全固体電池では，電解質が固体 であるため，活物質が電解液中へ脱落することなく，良好な
サイクル特性を示す7).しかしながら，充放電にともなう金属 インジウムの体積変化は，コイン型全固体電池の外寸变化を 引き起こし, 電子機器への実装に際し, 寸法的な課題を有し ていた。

一方,リチウムイオンの㨂入・脱離によって起こる結晶構 造の変化が極好て小さな材料としてチタン酸リチウム $\left(\mathrm{Li}_{4 / 3}{ }^{-}\right.$ $\left.\mathrm{Ti}_{5 / 3} \mathrm{O}_{4}\right)$ が知られており, この材料についての電気化学反応 は, $1.55 \mathrm{~V}\left(\mathrm{vs} . \mathrm{Li}^{+} / \mathrm{Li}\right)$ 付近で可逆的に進行することが報 告されている8.9.

本研究では, 電池寸法の変化を抑え, かつ電池電圧をメモ リーバックアップ用に適合させることを目的として, 負極活 物質にチタン酸リチウム $\left(\mathrm{Li}_{4 / 3} \mathrm{Ti}_{5 / 3} \mathrm{O}_{4}\right)$ を用いた $\mathrm{R} 1216$ サ イズのコイン型の全固体リチウム二次電池を作製し，その特 性について調バた.

\section{1 コイン型全固体電池の作製 \\ 2 実 験}

本電池の作製に際して, 使用した固体電解質ガラスは $\mathrm{Li}_{3} \mathrm{PO}_{4}, \mathrm{Li}_{2} \mathrm{~S}, \mathrm{SiS}_{2}$ をモル比で1：63：36に混合したも のをグラッシーカーボン製るつぼに入れ，乾燥絰素霍围気中 $1000{ }^{\circ} \mathrm{C}$ で 2 時間加熱溶融し，その融液を双ローラー法により 超急冷し，作製した，得られた固体電解質ガラスを平均粒径 が 1.5 3.0 $\mu \mathrm{m}$ となるよう粉砕し, 使用した.

また，正極はコバルト酸リチウム $\left(\mathrm{LiCoO}_{2}\right)$ と予め粉砕し た固体電解質粉末を重量比で $6: 4$ となるように，アルゴン 
ボックス中でアルミナ製ボール（直径 $3 \mathrm{~mm}$ ）を用いたボー ルミルで 1 時間混合し，正極合剤とした。

負極はスピネル構造を有するチタン酸リチウム $\left(\mathrm{Li}_{4 / 3} \mathrm{Ti}_{5 / 3}-\right.$ $\left.\mathrm{O}_{4}\right)$ と固体電解質粉末を重量比で $4: 6$ となるように, ボール ミルで 18 時間混合し，負極合剂とした。

前記固体電解質粉末 $20 \mathrm{mg}$ と正極合剤 $70 \mathrm{mg}$, さらに負 極合㓮 $70 \mathrm{mg}$ をアルゴン雾囲気下でプレス機を用い，三層 一体に成形し，このペレットをR1216サイズ（直径 12 $\mathrm{mm}$, 厚さ $1.6 \mathrm{~mm}$ ）のコイン型電池ケースに捕入して封口 L, Fig. 1 に示すコイン型全固体リチウム二次電池を作製し た.

本コイン型電池の容量は，(1)式の反応をもとに，正極活物 質の理論容量を $124 \mathrm{mAh} / \mathrm{g}$ として設計した。

$$
\mathrm{LiCoO}_{2} \rightarrow \mathrm{Li}_{1-x} \mathrm{CoO}_{2}+x \mathrm{Li}^{+}+x \mathrm{e}^{-} \quad(0 \leqq x \leqq 0.45)
$$

また，負極活物質の容量は，(2)式の反応をもとに，理論容 量を $175 \mathrm{~mA} \mathrm{~h} / \mathrm{g}$ とし設計した。

$$
\begin{aligned}
& \mathrm{Li}\left[\mathrm{Li}_{1 / 3} \mathrm{Ti}_{5 / 3}\right] \mathrm{O}_{4}+y \mathrm{Li}^{+}+\mathrm{ye}^{-} \rightarrow \\
& \mathrm{Li}_{1+y}\left[\mathrm{Li}_{1 / 3} \mathrm{Ti}_{5 / 3}\right] \mathrm{O}_{4} \quad(0 \leqq y \leqq 1)
\end{aligned}
$$

したがって，ここで用いた正極合剤 $70 \mathrm{mg}$ は $5.2 \mathrm{mAh}$, 負極合剤 $70 \mathrm{mg}$ は $4.9 \mathrm{mAh} の$ 理論容量となり, 充放電容量 は負極容量により規制される設計としな。

\section{2 電池特性の測定}

2. 2 . 1 充放電特性本電池の充放電特性について, 充 電及び放電の電流值をそれぞれ $150 \mu \mathrm{A}$, 放電終止電压を $1.0 \mathrm{~V}$, 充電終止電压を $3.5 \mathrm{~V}$ とし, また雲囲気温度 $20{ }^{\circ} \mathrm{C} の$ 下，定電流法により調べた。

\section{2.2 放電負荷特性放電負荷特性については雾囲} 気温度 $20{ }^{\circ} \mathrm{C}$ の下 $150 \mu \mathrm{A}$ で充電した後, その放電特性につ いて調べた．放電の際，霖囲気温度 $20{ }^{\circ} \mathrm{C}$ では $50,150,300$, $500 \mu \mathrm{A}$ ，また，60 ${ }^{\circ} \mathrm{C} て ゙ は ~ 150 ， 300 ， 500 \mu \mathrm{A}$ 扝よび $1 \mathrm{~mA}$ の範囲の定電流で放電性能を調べた。

\section{2. 3 定電圧充電特性定電圧充電特性について雾} 囲気温度 $20{ }^{\circ} \mathrm{C}$ の下で調べた. 充電の際, 充電電流値の上限を $500 \mu \mathrm{A}$ とし, 充電限界電圧を $2.5 \mathrm{~V}$ および $3.5 \mathrm{~V}$ の準定電 圧 (定電流-定電圧)として，これらの限界電圧で各々，24 時 間充電した後, 各電池を $150 \mu \mathrm{A}$ の定電流放電を行った。 た

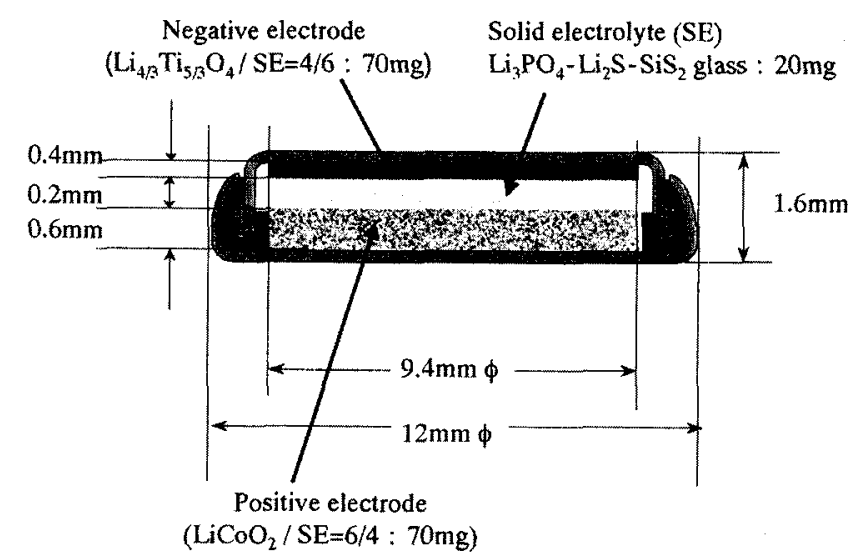

Fig. 1 Cross sectional view of the 1216 size solid state battery.
だし，その際の放電時の終止電圧は $1.0 \mathrm{~V}$ とた。

\section{3 結果および考察}

\section{1 充放電特性}

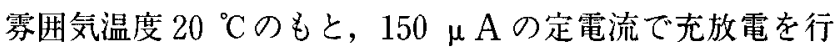
った際の充放電特性を Fig. 2 に示した.この図からわかるよ うに, 充放電効率はほぼ $100 \%$ \%作動し, $2.8 \mathrm{mAh}$ の放電電 気量が得られた. また，この電池についての充放電サイクル 特性を Fig. 3 に示した. 初期の 15 サイクルまでは放電容量 がわずかに低下するものの，その後は 100 サイクルを超えて もほとんど放電容量の低下は認められない，また，充放電効 率の推移もほぼ $100 \%$ \%でり，良好なサイクル特性が得られ ることがわかった。

この結果は，本固体リチウム二次電池では優れたイオン伝 導性を持ち，かつ分解電圧が極めて高いLiイオン伝導性才 キシサルファイドガラス ${ }^{10)}$ の使用によるものであり，無機固 体電解質を用いた固体電池は，充放電時において，有機溶媒 を電解液に用いた電池に見られるような，電解液の分解やそ れに伴うがス発生による充電電気量のロスが極めて小さいた め, サイクル特性劣化が極めて小さくなったものと考えられ る.また，これに加えて，本電池系ではリチウムイオンの挿 入・脱離反応が高い可逆性をもっている正極活物質として

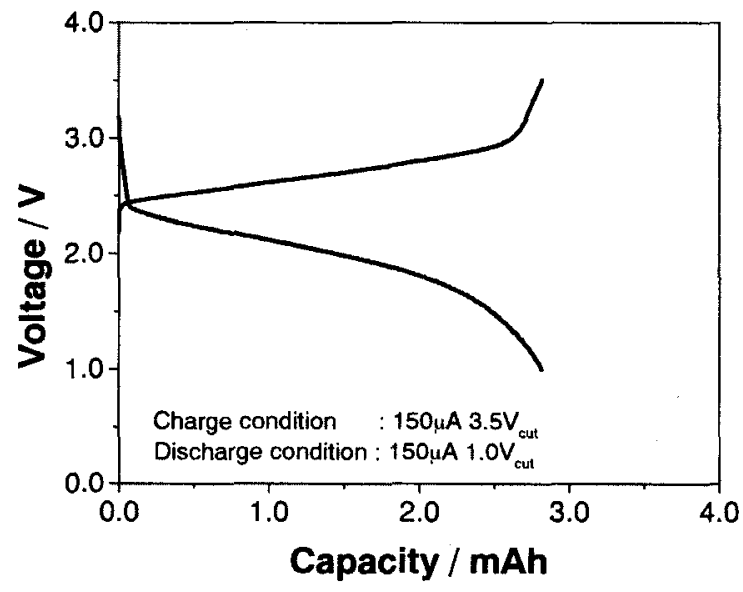

Fig. 2 Charge - discharge curves of the 1216 size coin type solid state battery.

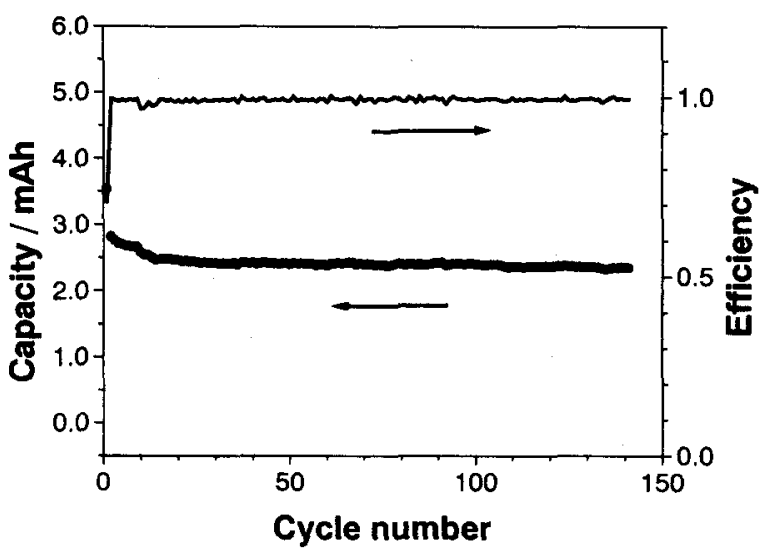

Fig. 3 Charge - discharge cycling characteristics of the 1216 size coin type solid state battery. 
$\mathrm{LiCoO}_{2}$, まな, 負極活物質として充放電にともなう体積变化 が少ない $\mathrm{Li}_{4 / 3} \mathrm{Ti}_{5 / 3} \mathrm{O}_{4}$ を用いたことで，このように優れたサ イクル特性を示すコイン型電池となったものと考えられる。

\section{2 放電角荷特性}

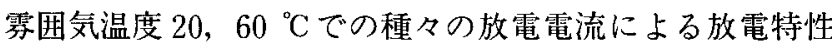

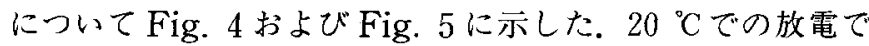
は, 放電電流が $50 \mu \mathrm{A}$ の場合， $3.0 \mathrm{mAh}$ の容量が，また， $150 \mu \mathrm{A}$ では $2.8 \mathrm{mAh}$ の放電容量が得られ, さらに500 $\mathrm{AA}$ での放電の場合でも， $2.0 \mathrm{mAh}$ の容量が得られ，これは 150 $\mu \mathrm{A}$ の定電流放電時の 70 \%に相当する優れた容量となって いる. 一方， $60{ }^{\circ} \mathrm{C}$ での放電では放電電流が $150 \mu \mathrm{A}$ の場合, $3.1 \mathrm{mAh}$ の容量が，また， $300 \mu \mathrm{A}$ では $3.0 \mathrm{mAh}$ の放電容 量が得られた.さらに, $1 \mathrm{~mA}$ の電流で放電した場合でも 2.9 $\mathrm{mAh}$ の容量が得られ, $150 \mu \mathrm{A}$ で放電した場合の $90 \%$ 以上 の容量が得られることがわかった。

\section{3 定電圧充電特性}

$20{ }^{\circ} \mathrm{C}$ の雾囲気のもと，3.5 V（電流制限 $500 \mu \mathrm{A}$ ）の定電 圧で 24 時間充電した際の充放電特性を Fig. 6 に示した。 ま た $2.5 \mathrm{~V}$ (電流制限 $500 \mu \mathrm{A})$ の定電圧で 24 時間充電した際 の充放電特性について Fig. 7 に示した.

$3.5 \mathrm{~V} て ゙ 24$ 時間充電した際の放電容量は定電流充放電で 得られた容量と同等の $2.8 \mathrm{mAh} の$ 容量が得られており,こ

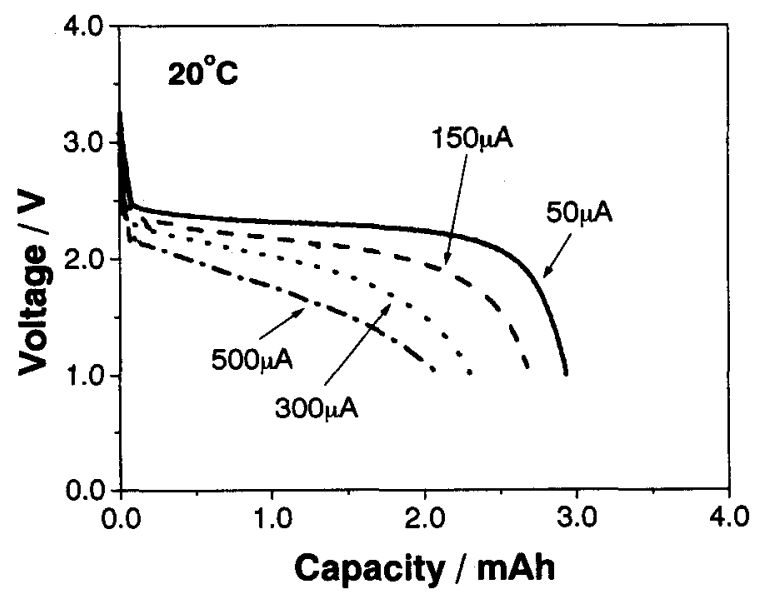

Fig. 4 Discharge curves at various currents at $20^{\circ} \mathrm{C}$.

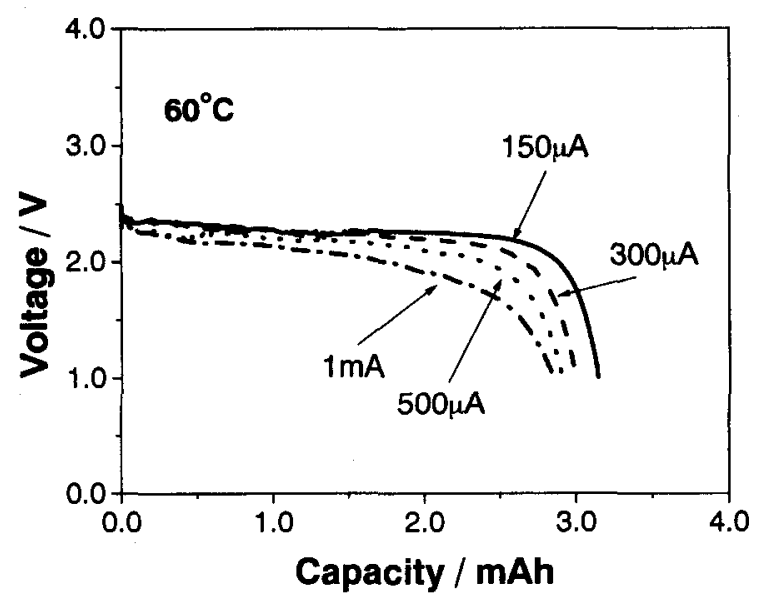

Fig. 5 Discharge curves at various currents at $60^{\circ} \mathrm{C}$.

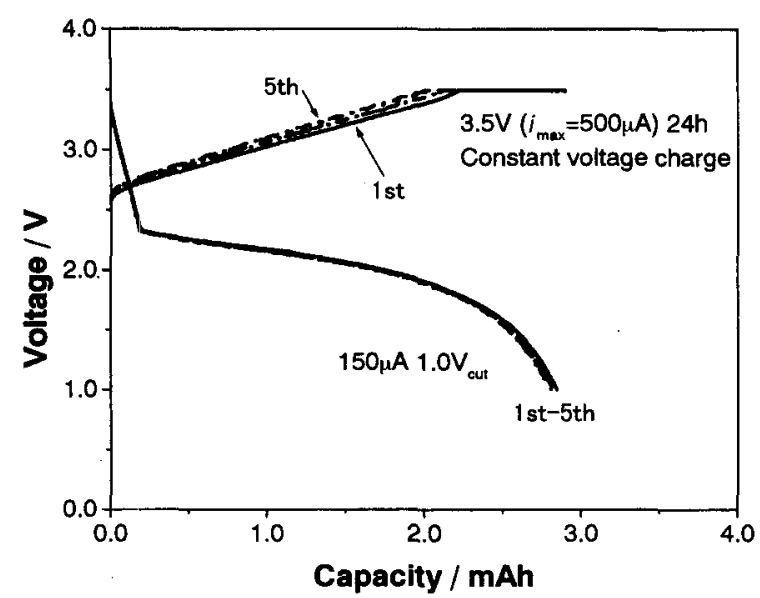

Fig. 6 Voltage profile of the cell charged at constant voltage $(3.5 \mathrm{~V})$ and then discharged at constant current $(150 \mu \mathrm{A})$.

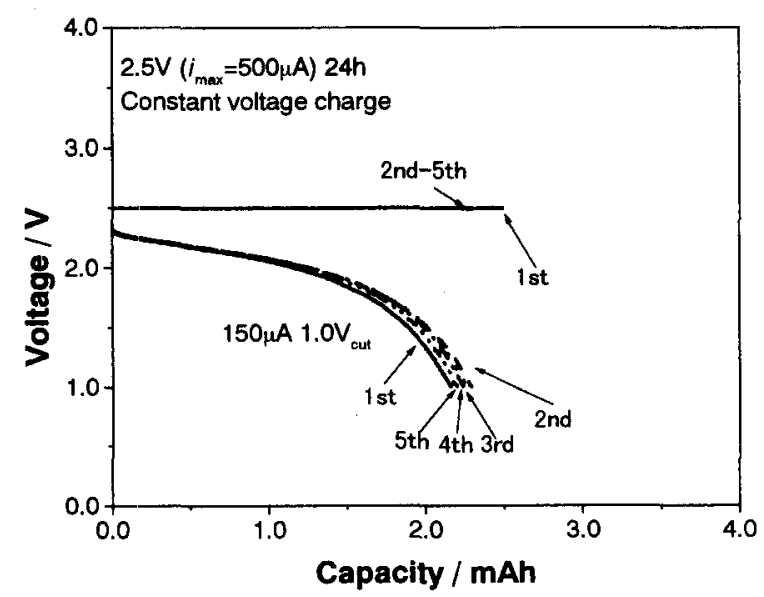

Fig. 7 Voltage profile of the cell charged at constant voltage $(2.5 \mathrm{~V})$ and then discharged at constant current $(150 \mu \mathrm{A})$.

の電池は, $3.5 \mathrm{~V}$ (電流制限 $500 \mu \mathrm{A}) 24$ 時間の充電ではフル 充電となることがわかった

また，この際の充放電サイクル特性についても定電流充放 電法で示したものと同じく，良好なサイクル特性を示した。

一方，2.5 Vで 24 時間充電した電池では，放電容量は 2.2 $\mathrm{mAh}$ と放電容量は $3.5 \mathrm{~V}$ 充電時よりも減少することがわか った，また，そのサイクル特性は極めて優れていた。

Fig. 8 には, $2.5 \mathrm{~V}$ (電流上限 $500 \mu \mathrm{A}$ ) の定電圧で連続 充電した際の電流の減衰挙動と充電電気量の変化について示 した．この图の充電電気量の時問变化からわかるように，約 25 時間で $2.2 \mathrm{mAh}$ に達しており，その後，充電時間を延長し た場合でも光電電気量はほほ飽和となり，170 時間充電した 場合でも， $2.4 \mathrm{mAh}$ にとどまる。これはFig. 8 に示したよ jに，充電電流が 100 時間後には $1 \mu \mathrm{A}$ 以下となり，ほとん ど電流が流れなくなることによるものである。

また，充電後，この電池を $150 \mu \mathrm{A} の$ 定電流で放電させた ところ Fig. 9 に示したように $2.4 \mathrm{mAh} の$ 放電容量が得られ た.すなわち，定電圧充電で充電した電気量のすべてが放電 可能な電池となっていることがわかった. 


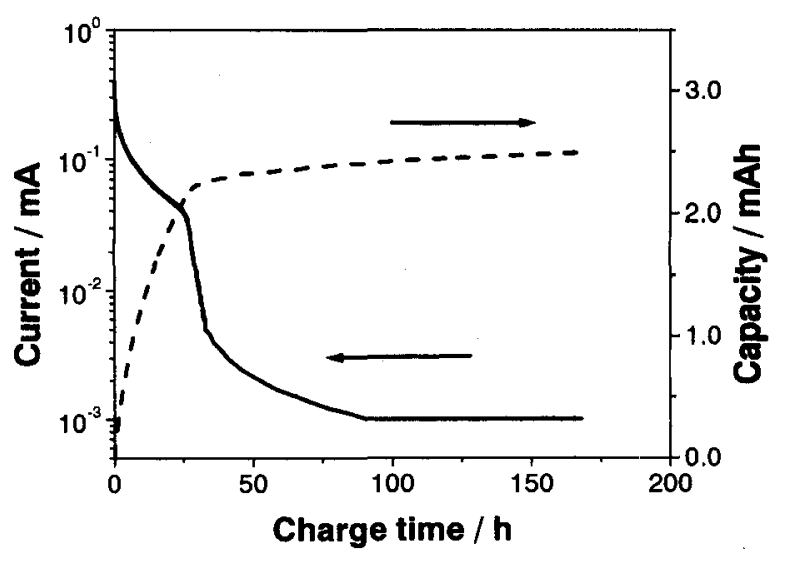

Fig. 8 Current decay during charging at a constant voltage of $2.5 \mathrm{~V}$. Charged capacity was calculated by integrating the current.

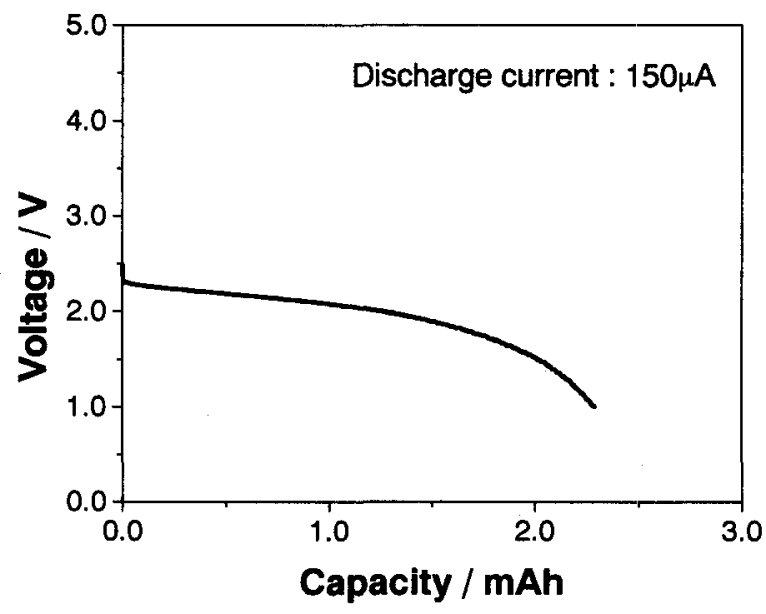

Fig. 9 Discharge curve of the battery after charging in indicated in Fig. 8.
以上の結果, 本電池がフロート充電に対してきわめて高い 耐性を示した原因として, 固体電解質の高い分解電圧 ${ }^{10)}$ に加 えて，充放電の際における構造変化が少ないスピネル型材料 を負極活物質に用いたことによるものと考えられる。

\section{4 まとめ}

固体電解質として $\mathrm{Li}_{3} \mathrm{PO}_{4}-\mathrm{Li}_{2} \mathrm{~S}-\mathrm{SiS}$ からなるリチウム イオン伝導性ガラスを用い, 負極活物質として, $\mathrm{Li}_{4 / 3} \mathrm{Ti}_{5 / 3}$ $\mathrm{O}_{4}$, 正極活物質として $\mathrm{LiCoO}_{2}$ を用いたコイン型全固体りチ ウム二次電池の特性を調べた。 その結果, $\mathrm{Li}_{3} \mathrm{PO}_{4}-\mathrm{Li}_{2} \mathrm{~S}-\mathrm{SiS} \mathrm{S}_{2}$ 固体電解質ガラスを用いたコイン型全固体リチウム二次電池 は, 従来の電解液式リチウム二次電池では得られない極めて 副反応の少ない電池となることがわかった．特に，充放電サ イクル特性とフロート充電特性に優れていた。

\section{文 献}

1) S. Kondo, K. Takada, and Y. Yamamura, Solid State Ionics, 53-56, 1183 (1992).

2) K. Takada, N. Aotani, and S. Kondo, J. Power Sources, 43-44, 135 (1993).

3) M. Tatsumisago, K. Hirai, T. Minami, K. Takada, and S. Kondo, J. Ceram. Soc. Jpn., 101, 1315 (1993).

4) N. Aotani, K. Iwamoto, K. Takada, and S. Kondo, Solid State Ionics, 68, 35 (1994).

5) 岩本和也, 藤野 信, 高田和典, 近藤繁雄, 電気化学 (presently Electrochemistry), 65, 753 (1997).

6) 脇原將孝編，最新電池技術，リアライズ社，p. 448 (1990).

7) K. Iwamoto, N. Aotani, K. Takada, and S. Kondo, Solid State Ionics, 79, 288 (1995).

8) T. Ohzuku, A. Ueda, and N. Yamamoto, J. Electrochem. Soc., 142, 1431 (1995).

9) 小柴信晴, 高田堅一, 中西 真, 浅香之み, 竹原善一郎, 電気 化学 (presently Electrochemistry), 62, 870 (1994).

10) K. Takada, N. Aotani, K. Iwamoto, and S. Kondo, Solid State Ionics, 86-88, 877 (1996). 